\title{
Production, technology and capacity planning for textile industry: A case study
}

\author{
Masoud Rabbani*, Mehrdad Niyazi and Hamed Rafiei
}

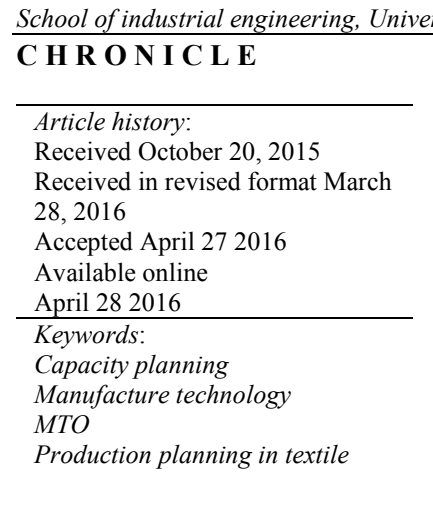

\begin{abstract}
A B S T R A C T
This paper presents a mathematical model to choose appropriate technology for production and capacity planning. The proposed study considers manufacturing planning in textile industry as a make-to-order (MTO) system by managing employees and water consumption and the possibility of outsourcing. The resulted model has been formulated as a mixed integer programming problem, which can be solved using a commercial software package. The implementation of the proposed study has been considered for a real-world case study and the results are discussed.
\end{abstract}

\section{Introduction}

Production planning studies in textile industry has been a challenging task and many existing problem formulations are not able to consider all major and critical constraints of the textile industry. Water is the most important component of textile firms and an economic method of water supplement plays essential role for the success of the firms in this industry. Staffing and optimizing the number of workers for each shift is another important and critical constraint. In this study we attempt to propose a model which considers the two mentioned constraints. Also setup and failure time which are common in textile firms are considered for the proposed model and the case study is a production of three kinds of yarns. There are two types of technologies to produce yarns where each has its own capacity for production. The firm works in three shifts and an upper and lower numbers of required workers for each shift is known. We assume that all workers are able to work with two technologies. With regard to management experience and historical data, failure and setup times are determined. Rest and failure times are reduced from the total time. The amount of input water to firm in each day is different and this influences on daily amount of production. In this case orders receive weekly and in eleven months of the year orders are the same but in month twelve (due to New Year) orders are different and production planning for this month is also different. Unit operation costs and capacity addition cost for the first * Corresponding author Tel: +98-2188350642 Fax: +98-2188350642

E-mail address: vikasgaur01@gmail.com (M. Rabbani) 
month is given and the corresponding costs for subsequent months were determined using a discount factor, e.g. 0.02, for each month. Also selling prices for month one is given and for other months a discount factor of, e.g. 0.05, is used. Holding costs belong to inventory at the end of each period (week). Daily available capacity can is available based on hourly basis. Since textile industry is a MTO industry, there is a limitation related to this issue that is so important.

Collins and Glendinning (2004) proposed a process for production planning in textile industry. Fuzzy linear programming was used to determine monthly production planning details and profit for a textile company by Elamvazuthi et al. (2010). In their research recursive method was introduced. Ferraris and Morini (2004) stated that matching tasks to units, under additional constraints, is the key issue in production planning in textile industry. De Toni and Meneghetti (2000) presented a model for production planning of network of textile firms. The main objective of their study was to investigate how the production planning process could affect the network performance from a time-based point of view. Chen et al. (2002) presented a stochastic programming approach for technology and capacity planning where in their model there were two types of technologies for production of two products. In their model, capacity addition was allowed. The objective was to allocate capacity for each of the technologies. Karacapilidis and Pappis (1996) presented an interactive model based system for the management of production in textile production systems focusing on the Master Production Scheduling (MPS) problem. The objective of the problem was to present work for designing a Decision Support System (DSS) for the production management in the textile industry.

The decision support system (DSS) presented by Adamopoulos et al. (1994) considered production planning and scheduling system for a textile industry by studying a mixed production system (job-shop and flow-shop), such as textile industry. The primary objective was to find the effective combination of a database and a model based management system to merge existing expert knowledge. Calosso et al. (2003) explained in detail the structure for a standardized negotiation process happening in a multienterprise setting and presented three mixed-integer linear programming models implemented by various parties involved.

Ford and Rager (1995) developed an expert system to support an essential decision scenario in the textile industry, which is associated with a sequence of production planning decisions requirements to build a specific category of end product. Each decision in the sequence depends entirely on the combination of decisions made in the preceding stages. The resulting system was described and its application was shown through the presentation of a sample consultation. They also explained the integration of the expert system into a broader environment for textile manufacturing decision support. Forza and Vinelli (1997) explained the importance of quick response strategy in the textile-apparel industry chain and described some issues associated with the organizational, management and technological conditions necessary for the achievement of this strategy. Hodge et al. (2011) explained which lean principles are more appropriate for implementation in the textile industry. They investigated the use of lean manufacturing in the textile industry through interviews, plant tours and case studies. They also presented a model to use lean tools and principles in a textile environment.

Karabuk (2008) focused on demand uncertainty a challenge in developing yarn production plans and developed a stochastic programming model that explicitly incorporates uncertainty in terms of discrete demand scenarios. He also proposed a two-step pre-processing method, which improves the linear programming relaxation of the model. He explained the advantages of a stochastic programming approach over a deterministic model and shared some initial application experiences. Yüksel and Dagdeviren (2007) explained a process for quantitative Strengths, Weaknesses, Opportunities and Threats (SWOT) analysis performed even when there is dependence among strategic factors. They used the analytic network process, which helps measurement of the dependency among the strategic factors, as well as analytical hierarchy process, which is based on the independence between the factors. Dependency among the SWOT factors was observed to influence on the strategic and sub-factor weights, as well as to change the strategy priorities. 
Silva and Magalhaes (2006) presented an industrial problem of an acrylic company where various finished products were obtained from the same fiber generated in the spinning unit. The problem was a special case of the discrete lot sizing and scheduling problem by minimizing tool changeovers and the quantity of fiber delivered after the required due date. Ceryan and Koren (2009) studied optimal capacity investment strategies for companies producing two products over a planning horizon. They explained how a range of investment cost parameters, product revenues and demand uncertainties could affect the optimal strategy to whether invest in pure flexible, pure dedicated or a portfolio of both types of systems. Eppen et al. (1980) described a model developed for General Motors to help in making decisions about capacity for four of their auto lines. Also there are several studies in supply chain of textile firms such as lean supply (Bruce et al., 2004); leagile supply chain (Mason-Jones et al., 2000); simulation of a textile supply chain (Santana-Robles et al., 2012); etc.

This paper includes the following structure: Section 2 is the proposed model. Then, raw data and numerical results for our case is presented in section 3. Last but not least is the conclusion of this study in section 4.

\section{Proposed Model}

The objective function of the proposed study of this paper is to maximize the profit and also to give a technology and capacity planning. We consider the water consumption and staff rostering and also in case of the high demand the outsourcing is allowed.

\subsection{Assumptions}

The period is considered weekly;

There is no budget constraint to purchase raw material;

Initial inventory level is taken into account at time 0 ;

There are two type of technologies for manufacturing each product;

Workers are able to work with two types of technologies;

If needed firm can work three shifts per day and all days of the week;

Capacity addition is allowed if it is required.

2.2. Notation and Mathematical Model

\section{Parameters}

$k$ : Number of products; indexed as $1, \ldots, K$.

$t$ : Number of shifts; indexed as $1, \ldots, T$.

$j$ : Number of days; indexed as $1, \ldots, J$.

$w$ : Number of periods (weeks); indexed as $1, \ldots, W$.

$i$ : Number of technologies; indexed as $\mathrm{i}, \ldots, I$.

$V_{k}$ : Selling price of product $k$.

$U_{i k}$ : Unit operating cost for product $k$ by technology type $i$.

$C_{k}$ : Holding cost for product $k$.

$F_{i k}$ : Cost of capacity addition of first technology for product $k$. 
$\delta$ : Cost of 1 liter of water.

$\theta_{k}$ : The amount of water consumption to produce one unit of product $k$.

$C_{t j}$ : Cost of shift $t$ in day $j$.

$P_{i k}$ : Product rate for product $k$ by technology type $i$.

$\mu_{i j w:}$ Available time for technology type $i$ in day $j$ of period $w$.

$e_{i j w:}$ Setup time for technology type $i$ in day $j$ of period $w$.

$Q_{j w}$ : Input amount of water to firm in day $j$ of period $w$.

$H_{i 0}$ : The capacity of technology type $i$ at the beginning of period 1 .

$b_{k}$ : The initial inventory of product $k$ at the beginning of period 1 .

$D_{k w}$ : The demand of product $k$ in period $w$.

Decision variables

$X_{i k w}$ : The amount of technology type $i$ allocated to product $k$ in period $w$.

$X_{i k j w}$ : The amount of technology type $i$ allocated to product $k$ in period $w$ in day $j$.

$Z_{i k w}$ : The amount of capacity addition for technology type $i$ at the beginning of period $w$.

$I_{k w}$ : The amount of inventory of product $k$ at the end of time period $w$.

$L_{j}$ : Number of required workers for day $j$.

$Y_{t j}$ : Number of workers working shift $t$ in day $j$.

$V_{k j w}$ : Boolean variable that equals to 1 if in day $j$ of period $w$ the production type $k$ is produced and 0 otherwise.

Mathematical model:

$$
\begin{aligned}
& \max z=\sum_{i}^{I} \sum_{k}^{K} \sum_{w}^{W} V_{k} X_{i k w}-\sum_{t}^{T} \sum_{j}^{J} C_{t j} Y_{t j}-\sum_{i}^{I} \sum_{k}^{K} \sum_{w}^{W} U_{i k} X_{i k w}+ \\
& +C_{k} I_{k w}-\sum_{i}^{I} \sum_{k}^{K} \sum_{w}^{W} F_{i k} Z_{i k w}-\delta \sum_{i}^{I} \sum_{k}^{K} \sum_{j}^{J} \sum_{w}^{W} \theta_{k} X_{i k j w}
\end{aligned}
$$

subject to

$$
\begin{array}{ll}
b_{k}+X_{i k 1}=I_{k 1}+D_{k 1} & i=1, \ldots, I, k=1, \ldots, K, \\
I_{k, w-1}+X_{i k w}=I_{k w}+D_{k w} & i=1, \ldots, I \quad k=2, \ldots, K w=2, \ldots, W \\
J & i=1, \ldots, I \\
\sum_{j}^{J} X_{i k j w} \geq D_{k w} & k=2, \ldots, K \\
X_{i k w} \leq H_{i 0} & w=2, \ldots, W \\
\sum_{k}^{K} \theta_{k} X_{i k j w} \leq Q_{j w} & i=1, \ldots, I k=2, \ldots, K w=2, \ldots, W \\
& i=1, \ldots, I k=2, \ldots, K w=2, \ldots, W
\end{array}
$$




$$
\begin{array}{ll}
\sum_{k}^{K} \frac{X_{i k j w}}{P_{i k}}+V_{k j w} e_{i j w} \leq \mu_{i j w} & i=1, \ldots, I j=1, \ldots, J w=2, \ldots, W \\
V_{k j w} \leq X_{i k j w} & i=1, \ldots, I j=1, \ldots, J k=2, \ldots, K w=2, \ldots, W \\
X_{i k w} \leq M V_{k j w} & \begin{array}{l}
i=1, \ldots, I j=1, \ldots, J k=2, \ldots, K w=2, \ldots, W \\
j=1, \ldots, J
\end{array} \\
\sum_{k}^{K} Y_{t j} \geq L_{j} & \\
15 \leq Y_{1 j} \leq 18 & \\
15 \leq Y_{2 j} \leq 18 & j=1, \ldots, J \\
15 \leq Y_{3 j} \leq 18 & j=1, \ldots, J \\
X_{i k w} \geq 0 & \\
X_{i j k w} \geq 0 & \\
Y_{t j} \geq 0 \text { and integer } & \\
V_{k j w} \in\{0,1\} & \\
I_{k w} \geq 0 &
\end{array}
$$

The objective function maximizes the profit. First term of the right hand side of the equation is total income from selling the production in each period. Second term shows the total staffing cost. In the third term we calculate total operation and holding cost. Capacity addition cost is calculated in the fourth term of the equation. In the last term, the cost of water consumption in each day is calculated.

Eq. (2) and Eq. (3) specify that demand be satisfied for each product in each period; in production planning these constraints are called "inventory balancing". Eq. (4) is the make-to-order constraint and shows that we have to response the orders that receive weekly. Eq. (4) shows the capacity constraint of the production and states that the amount of production cannot exceed the production capacity. The limitation of water consumption is denoted in Eq. (6). Eq. (7) is capacity loading constraint that indicates that total production time plus setup times should be lower than the available time for each technology. Eq. (8) and Eq. (9) denote that if in $j^{\text {th }}$ day of period $w$ production of product $k$ is performed we have the setup time, if not there is no setup time. Eqs. (10)-(13) determine the staffing; Eq. (10) is the staffing coverage constraint that shows that the total number of workers in each shift for each day should be greater than number of required workers for that day and Eqs. (11-13) are the lower and upper number of required workers for each shift.

\section{Numerical results}

In this paper we have studied a case of textile firm in city of Qazvin, Iran which produces three kinds of yarn with two types of technologies. This firm works at three shifts and orders are received on weekly basis. In the events of high demand, increase in capacity is allowed. For water consumption there is a limitation because of limited amount of input water to the firm. In this case we have four periods (weeks) but also we consider 12 months of the year, because we want to have a production planning for a year. Unit operation costs for each product by each technology for the first month is given and the corresponding costs for subsequent periods were determined using a discount factor of 0.02 for each period. Also selling prices for the first month is given and a discount factor of 0.05 is used for determining the other months. In our case the costs and selling prices for the three first month are different because of the seasonal effect and also because in the first months of the New Year the economic condition is turbulent. But from the $4^{\text {th }}$ month to $6^{\text {th }}$ month the cost are constant. Also in month 7 because of the beginning of academic year the cost are discounted too. Between the $7^{\text {th }}$ and $12^{\text {th }}$ months the costs are constant too and in month 12 that is near to the New Year the cost and also 
demands are different and demands are increased. For sample, data for $1^{\text {st }}$ month and $12^{\text {th }}$ month are shown in Table 1 and Table 2, respectively.

We solve the model by GAMS software package but there are some certain issues that should be noticed in solution procedure. First when we are solving, for example, for the second month, we have to consider that initial inventory of this month is obtained by the $1^{\text {st }}$ month and should modify the initial inventory. Secondly for month 12 the demand is increased, hence the number of required workers should be increased too and in order to response the demand the lower and upper number of workers per shifts are as follows:

$$
\begin{array}{ll}
15 \leq Y_{1 j} \leq 18 & j=1, \ldots, J \\
15 \leq Y_{2 j} \leq 18 & j=1, \ldots, J \\
15 \leq Y_{3 j} \leq 18 & j=1, \ldots, J
\end{array}
$$

Now we analyze the outcomes of the solution:

\begin{tabular}{|c|c|c|c|c|c|c|c|c|c|c|c|c|c|c|c|c|}
\hline \multirow[t]{2}{*}{ 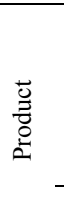 } & \multicolumn{4}{|c|}{$\begin{array}{l}\text { Demand of each } \\
\text { period }(\mathrm{kg})\end{array}$} & \multirow[t]{2}{*}{$\begin{array}{l}\text { Selling } \\
\text { price } \\
\text { of each } \\
\text { product } \\
\quad(\$)\end{array}$} & \multicolumn{3}{|c|}{$\begin{array}{l}\text { Unit operation } \\
\text { cost for each } \\
\text { product by each } \\
\text { technology }(\$)\end{array}$} & \multicolumn{3}{|c|}{$\begin{array}{l}\text { Unit capacity } \\
\text { addition for } \\
\text { product } k \text { by } \\
\text { technology } i \\
\text { (\$) }\end{array}$} & \multirow[t]{2}{*}{$\begin{array}{l}\text { Holding } \\
\text { cost for } \\
\text { each } \\
\text { product } \\
\quad(\$)\end{array}$} & \multirow[t]{2}{*}{$\begin{array}{c}\text { Initial } \\
\text { inventory } \\
\text { of product } \\
k(\mathrm{~kg})\end{array}$} & \multirow[t]{2}{*}{$\begin{array}{l}\text { Amount of } \\
\text { water } \\
\text { consumption to } \\
\text { produce one } \\
\text { unit of product } \\
\text { (Li) }\end{array}$} & \multicolumn{2}{|c|}{$\begin{array}{c}\text { Product rate } \\
\text { for product } \\
k \text { by } \\
\text { technology } \\
\text { type } I \\
\text { (kg/hour) }\end{array}$} \\
\hline & 1 & 2 & 3 & 4 & & 1 & 2 & & & 1 & 2 & & & & 1 & 2 \\
\hline 1 & 4000 & 3500 & 2000 & 1900 & 5500 & 2900 & 31 & & & 00 & 2900 & 500 & 300 & 1 & 384 & 392 \\
\hline 2 & 4500 & 4000 & 3000 & 3000 & 6750 & 4250 & 40 & & & 00 & 4100 & 600 & 500 & 1.5 & 390 & 396 \\
\hline 3 & 2500 & 3500 & 2500 & 3000 & 7700 & 5200 & 49 & & & 00 & 5000 & 700 & 550 & 1 & 320 & 330 \\
\hline \multirow[t]{3}{*}{ ڤొ } & \multirow{2}{*}{\multicolumn{4}{|c|}{$\begin{array}{l}\text { Cost of each shift } \\
\text { in day j } \\
\text { (\$) }\end{array}$}} & $\begin{array}{l}\text { Number } \\
\text { of } \\
\text { required }\end{array}$ & \multirow{2}{*}{\multicolumn{5}{|c|}{$\begin{array}{l}\text { Input amount of water to firm in } \\
\text { day } j \text { of period } w \text { (Li) }\end{array}$}} & & \multicolumn{2}{|c|}{$\begin{array}{c}\text { Available time for } \\
\text { technology type } i \text { in day } \\
j \text { of period } w(\mathrm{~h})\end{array}$} & \multicolumn{3}{|c|}{$\begin{array}{l}\text { Setup time for technology type } i \text { in day } j \text { of } \\
\text { period } w(\mathrm{~h})\end{array}$} \\
\hline & & & & & workers & & & & & & & 1 & 2 & 1 & 2 & \\
\hline & & 1 & 2 & 3 & & 1 & 2 & & & 4 & & $2,3,4$ & $1,2,3,4$ & $1,2,3,4$ & $1,2,3$ & \\
\hline 1 & & 28000 & 32000 & 40000 & 45 & 2000 & 2000 & 20 & & 2000 & & 23 & 22 & 2.5 & 3.5 & \\
\hline 2 & & 28000 & 32000 & 40000 & 48 & 3000 & 3000 & 30 & & 3000 & & 22 & 21 & 2 & 2 & \\
\hline 3 & & 28000 & 32000 & 40000 & 50 & 2500 & 2500 & 25 & & 2500 & & 21.5 & 20.5 & 2.6 & 3 & \\
\hline 4 & & 28000 & 32000 & 40000 & 45 & 2000 & 2000 & 20 & & 2000 & & 22 & 21 & 3 & 3 & \\
\hline 5 & & 28000 & 32000 & 40000 & 47 & 3000 & 3000 & 30 & & 3000 & & 22.5 & 21.5 & 2 & 2.5 & \\
\hline 6 & & 28000 & 32000 & 40000 & 40 & 1000 & 1000 & 10 & & 1000 & & 23 & 22 & 2.5 & 2.5 & \\
\hline 7 & & 28000 & 32000 & 40000 & 38 & 1000 & 1000 & & & 1000 & & 22 & 21 & 1.5 & 2 & \\
\hline
\end{tabular}

Table 1

Data for $1^{\text {st }}$ month

Tables 3-8 show the amount of production of each product in each period for each month. Note that the results for months 3, 4, 5 and 6 are the same and also results for months $8,9,10$ and 11 are the same. For example for $1^{\text {st }}$ month, we can see that for technology type 2 in period 3 and for product type 1 the optimal amount is equal to $1 \mathrm{~kg}$. It is not reasonable and economic for the firm to produce just for $1 \mathrm{~kg}$ and we should allocate this $1 \mathrm{~kg}$ to another period or to technology type 1 . Also in Table 3 it is indicated that capacity addition is performed just for $2^{\text {nd }}$ technology in periods 1 and 2 and for products 1 and 2 . Also in this table, values of inventory at the end of each period are shown and the values for last period is the amount of initial inventory for the next month and for solving the next month the code should be modified with these values. Explanation of the Tables 4-7 are the same as Table 3. As shown in Tables 4 and 5, the amount of production for months 2-6 are almost the same and this simplifies production planning in these months. In $12^{\text {th }}$ month which results are shown in Table 8 we can see that as demand increases, capacity allocation of both technologies are increased and also in this month capacity addition is more than other months which regarding to high demand in this month, increasing amount of capacity addition was predictable. Note that in any months the capacity addition for technology type 1 is executed, which means that in some cases we can allocate some of the production of technology 
type 2 to type 1 without a significant change in the objective values. Table 9 and 10 are associated with the values for $\mathrm{X}_{\mathrm{ikjw}}$. We only present these two tables for instance and avoid mentioning results for other months.

In $12^{\text {th }}$ month that result are shown in Table 10 the amount of production for each day of each period for each product is presented. Again in this table there are some 1 values which we should pay attention to these 1 values. We should allocate these values to another technology or other periods. For example for technology type 1 that produces product 1 there are four 1 values, if we allocate these values to technology type 2 the differences between the objectives is 800 , and is not significant, hence doing this change is reasonable. Tables 11 and 12 are the number of required workers for each shift. Since the required number of workers for all the months, except month 12, are the same there are two types for staffing that are shown in Tables 11 and 12 for months 1-11 and month 12 respectively.

Table 2

\begin{tabular}{|c|c|c|c|c|c|c|c|c|c|c|c|c|c|c|c|}
\hline \multirow[t]{2}{*}{$\begin{array}{l}\bar{U} \\
\tilde{\Xi} \\
0 \\
0 \\
0\end{array}$} & \multicolumn{4}{|c|}{$\begin{array}{l}\text { Demand of each } \\
\text { period }(\mathrm{kg})\end{array}$} & \multirow[t]{2}{*}{$\begin{array}{l}\text { Selling } \\
\text { price of } \\
\text { each } \\
\text { product } \\
\text { (\$) }\end{array}$} & \multicolumn{3}{|c|}{$\begin{array}{l}\text { Unit operation cost for } \\
\text { each product by each } \\
\text { technology }(\$)\end{array}$} & \multicolumn{2}{|c|}{$\begin{array}{l}\text { Unit capacity addition } \\
\text { for product } k \text { by } \\
\text { technology } i(\$)\end{array}$} & \multirow[t]{2}{*}{$\begin{array}{l}\text { Holding } \\
\text { cost for } \\
\text { each } \\
\text { product } \\
\text { (\$) }\end{array}$} & \multirow[t]{2}{*}{$\begin{array}{l}\text { Initial } \\
\text { inventory } \\
\text { of } \\
\text { product } k \\
(\mathrm{~kg})\end{array}$} & \multirow[t]{2}{*}{$\begin{array}{l}\text { Amount of } \\
\text { water } \\
\text { consumption } \\
\text { to produce } \\
\text { one unit of } \\
\text { product (Li) }\end{array}$} & \multicolumn{2}{|c|}{$\begin{array}{c}\text { Product rate } \\
\text { for product } k \\
\text { by } \\
\text { technology } \\
\text { type } I \\
(\mathrm{~kg} / \mathrm{hour}) \\
\end{array}$} \\
\hline & 1 & 2 & 3 & 4 & & 1 & & & 1 & 2 & & & & 1 & 2 \\
\hline 1 & 4500 & 3700 & 2400 & 2100 & 6370.29 & 3139.05 & \multicolumn{2}{|c|}{3355.53} & 3463.79 & 3139.05 & 500 & 2601 & 1 & 384 & 392 \\
\hline 2 & 4800 & 4400 & 3300 & 3400 & 8204.67 & 4600.33 & \multicolumn{2}{|c|}{4329.73} & 4870.95 & 4437.97 & 600 & 500 & & 390 & 396 \\
\hline 3 & 2800 & 3800 & 2700 & 3200 & 9359.4 & 5628.65 & \multicolumn{2}{|c|}{5303.92} & 5628.65 & 5412.12 & 700 & 1250 & $\begin{array}{c}1.5 \\
1\end{array}$ & 320 & 330 \\
\hline \multirow[t]{3}{*}{ बे } & \multirow{2}{*}{\multicolumn{4}{|c|}{$\begin{array}{l}\text { Cost of each shift } \\
\text { in day } \mathrm{j} \\
(\$)\end{array}$}} & \multirow{3}{*}{$\begin{array}{l}\text { Number } \\
\quad \text { of } \\
\text { required } \\
\text { workers } \\
\text { for day } j\end{array}$} & \multicolumn{6}{|c|}{$\begin{array}{l}\text { Available time for } \\
\text { technology type } i \text { in } \\
\text { day } j \text { of period } w(\mathrm{~h})\end{array}$} & \multicolumn{4}{|c|}{$\begin{array}{l}\text { Setup time for technology type } i \text { in day } j \\
\text { of period } w(\mathrm{~h})\end{array}$} \\
\hline & & & & & & & & & & 1 & 2 & & & 2 & \\
\hline & & 1 & 2 & 3 & & 1 & 2 & 3 & 4 & $1,2,3,4$ & $1,2,3,4$ & 1,2 & 3,4 & $1,2,3$, & \\
\hline 1 & & 28000 & 32000 & 40000 & 49 & 2000 & 2000 & 2000 & 2000 & 23 & 22 & & & 3.5 & \\
\hline 2 & & 28000 & 32000 & 40000 & 52 & 3000 & 3000 & 3000 & 3000 & 22 & 21 & & & 2 & \\
\hline 3 & & 28000 & 32000 & 40000 & 53 & 2500 & 2500 & 2500 & 2500 & 21.5 & 20.5 & & & 3 & \\
\hline 4 & & 28000 & 32000 & 40000 & 48 & 2000 & 2000 & 2000 & 2000 & 22 & 21 & & & 3 & \\
\hline 5 & & 28000 & 32000 & 40000 & 50 & 3000 & 3000 & 3000 & 3000 & 22.5 & 21.5 & & & 2.5 & \\
\hline 6 & & 28000 & 32000 & 40000 & 47 & 1000 & 1000 & 1000 & 1000 & 23 & 22 & & & 2.5 & \\
\hline 7 & & 28000 & 32000 & 40000 & 42 & 1000 & 1000 & 1000 & 1000 & 22 & 21 & & & 2 & \\
\hline
\end{tabular}

Table 3

Results for the month 1

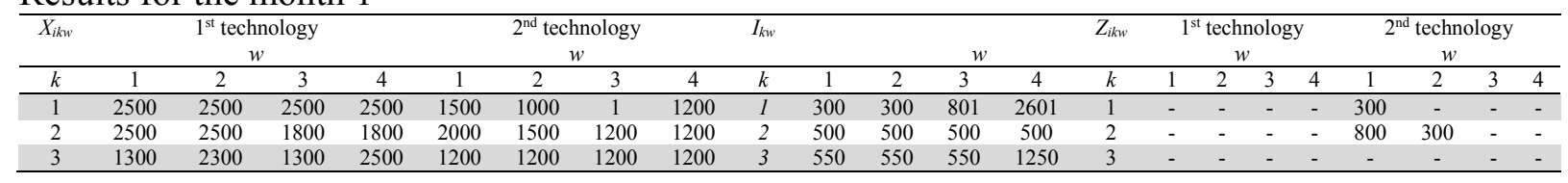

Table 4

Results for the month 2

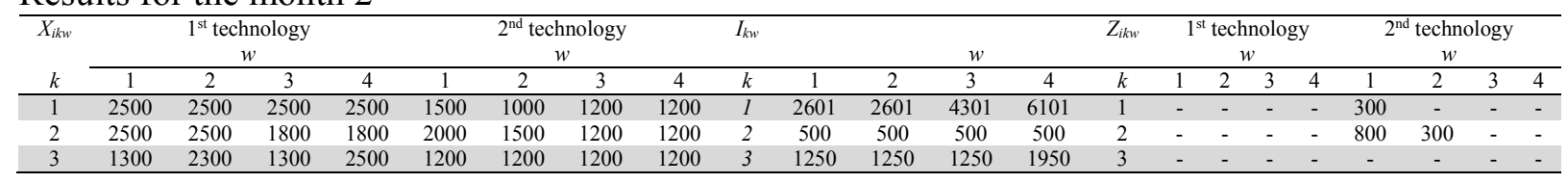

Table 5

Results for the month 3, 4, 5, 6

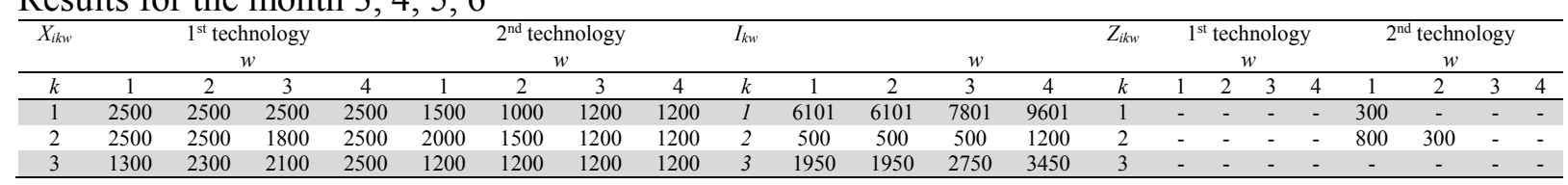


Table 6

Results for month 7

\begin{tabular}{|c|c|c|c|c|c|c|c|c|c|c|c|c|c|c|c|c|c|c|c|c|c|c|}
\hline \multirow{2}{*}{$\begin{array}{c}X_{i k w} \\
\\
k\end{array}$} & \multicolumn{4}{|c|}{$\begin{array}{c}1^{\text {st }} \\
\text { technology } \\
w\end{array}$} & \multicolumn{4}{|c|}{$\begin{array}{c}2^{\text {nd }} \\
\text { technology } \\
w\end{array}$} & \multicolumn{3}{|l|}{$I_{k w}$} & $w$ & & $Z_{i k w}$ & \multicolumn{4}{|c|}{$\begin{array}{c}1^{\text {st }} \text { technology } \\
w\end{array}$} & \multicolumn{4}{|c|}{$\begin{array}{c}2^{\text {nd }} \\
\text { technology } \\
w\end{array}$} \\
\hline & 1 & 2 & 3 & 4 & 1 & 2 & 3 & 4 & $k$ & 1 & 2 & 3 & 4 & $k$ & 1 & 2 & 3 & 4 & 1 & 2 & 3 & 4 \\
\hline 1 & 2500 & 2500 & 2500 & 2500 & 1500 & 1000 & 800 & 1200 & 1 & 6101 & 6101 & 7401 & 9201 & 1 & - & - & - & - & 300 & - & - & - \\
\hline 2 & 2500 & 2500 & 1800 & 2500 & 2000 & 1500 & 1200 & 1200 & 2 & 500 & 500 & 500 & 1200 & 2 & - & - & - & - & 800 & 300 & - & - \\
\hline 3 & 1300 & 2300 & 2500 & 2500 & 1200 & 1200 & 1200 & 1200 & 3 & 1950 & 1950 & 3150 & 3850 & 3 & - & - & - & - & - & - & - & - \\
\hline
\end{tabular}

\section{Table 7}

Results for month 8, 9, 10, 11

\begin{tabular}{|c|c|c|c|c|c|c|c|c|c|c|c|c|c|c|c|c|c|c|c|c|c|c|}
\hline \multirow{2}{*}{$\begin{array}{c}X_{i k w} \\
k \\
k\end{array}$} & \multicolumn{4}{|c|}{$\begin{array}{c}1^{\text {st }} \text { technology } \\
w\end{array}$} & \multicolumn{4}{|c|}{$\begin{array}{c}2^{\text {nd }} \text { technology } \\
w\end{array}$} & \multicolumn{3}{|l|}{$I_{k w}$} & \multicolumn{2}{|l|}{$w$} & $Z_{i k w}$ & \multicolumn{4}{|c|}{$\begin{array}{c}1^{\text {st }} \text { technology } \\
w\end{array}$} & \multicolumn{4}{|c|}{$\begin{array}{c}2^{\text {nd }} \\
\text { technology } \\
w\end{array}$} \\
\hline & 1 & 2 & 3 & 4 & 1 & 2 & 3 & 4 & $k$ & 1 & 2 & 3 & 4 & $k$ & 1 & 2 & 3 & 4 & 1 & 2 & 3 & 4 \\
\hline 1 & 2500 & 2500 & 2500 & 2500 & 1500 & 1000 & 800 & 1200 & 1 & 9201 & 9201 & 10501 & 12301 & 1 & - & - & - & - & 300 & - & - & - \\
\hline 2 & 2500 & 2500 & 1800 & 2500 & 2000 & 1500 & 1200 & 1200 & 2 & 1200 & 1200 & 1600 & 1900 & 2 & - & - & - & - & 800 & 300 & - & - \\
\hline 3 & 1300 & 2300 & 2500 & 2500 & 1200 & 1200 & 1200 & 1200 & 3 & 3850 & 3850 & 4850 & 5350 & 3 & - & - & - & - & - & - & - & - \\
\hline
\end{tabular}

\section{Table 8}

Results for month 12

\begin{tabular}{|c|c|c|c|c|c|c|c|c|c|c|c|c|c|c|c|c|c|c|c|c|c|c|}
\hline \multirow[t]{2}{*}{$X_{i k w}$} & \multicolumn{4}{|c|}{$\begin{array}{c}1^{\text {st }} \text { technology } \\
w\end{array}$} & \multicolumn{4}{|c|}{$\begin{array}{c}2^{\text {nd }} \text { technology } \\
w\end{array}$} & \multicolumn{2}{|l|}{$I_{k w}$} & & & & $Z_{i k w}$ & \multicolumn{4}{|c|}{$\begin{array}{c}1^{\text {st }} \text { technology } \\
w\end{array}$} & \multicolumn{4}{|c|}{$\begin{array}{c}2^{\text {nd }} \\
\text { technology } \\
w\end{array}$} \\
\hline & 1 & 2 & 3 & 4 & 1 & 2 & 3 & 4 & $k$ & 1 & 2 & 3 & 4 & $k$ & 1 & 2 & 3 & 4 & 1 & 2 & 3 & 4 \\
\hline 1 & 2500 & 2500 & 2500 & 2500 & 2000 & 1200 & 1200 & 1200 & 1 & 12301 & 12301 & 13601 & 15201 & 1 & - & - & - & - & 800 & - & - & - \\
\hline 2 & 2500 & 2500 & 2500 & 2500 & 2300 & 1900 & 1200 & 1200 & 2 & 1900 & 1900 & 2300 & 2600 & 2 & - & - & - & - & 1100 & 700 & - & - \\
\hline 3 & 1600 & 2500 & 2500 & 2500 & 1200 & 1300 & 1200 & 1200 & 3 & 5750 & 5750 & 6750 & 7250 & 3 & - & - & - & - & - & 100 & - & - \\
\hline
\end{tabular}

\section{Table 9}

Results of $\mathrm{X}_{\mathrm{ikjw}}$ for month 1

\begin{tabular}{|c|c|c|c|c|c|c|c|c|c|c|c|c|c|c|}
\hline $\mathrm{K}=1$ & & & & & $\mathrm{~K}=2$ & & & & & $\mathrm{~K}=3$ & & & & \\
\hline $\mathrm{j}$ & 1 & 2 & 3 & 4 & $j$ & 1 & 2 & 3 & 4 & j & 1 & 2 & 3 & 4 \\
\hline 1 & - & - & - & 203 & 1 & 1000 & 1332.33 & - & - & 1 & - & - & 1299 & - \\
\hline 2 & - & - & 2500 & - & 2 & 1499 & 1 & 331.67 & 1799 & 2 & 1 & 2298 & - & - \\
\hline 3 & - & - & - & 999 & 3 & 1 & 1165.67 & - & 1 & 3 & - & - & - & - \\
\hline 4 & 1999 & 501 & - & - & 4 & - & 1 & 1332.33 & - & 4 & - & - & - & - \\
\hline 5 & 499 & 1998 & - & 1297 & 5 & - & - & 136 & - & 5 & 1298 & & & 1701 \\
\hline 6 & 1 & - & - & 1 & 6 & - & - & - & - & 6 & 1 & 1 & 1 & 798 \\
\hline 7 & 1 & 1 & - & - & 7 & - & - & - & - & 7 & - & 1 & - & 1 \\
\hline
\end{tabular}

\section{Table 10}

Results of $\mathrm{X}_{\mathrm{ikjw}}$ for month 12

\begin{tabular}{|c|c|c|c|c|c|c|c|c|c|c|c|c|c|c|}
\hline $\mathrm{K}=1$ & & & & & $\mathrm{~K}=2$ & & & & & $\mathrm{~K}=3$ & & & & \\
\hline j & 1 & 2 & 3 & 4 & j & 1 & 2 & 3 & 4 & $\mathrm{j}$ & 1 & 2 & 3 & 4 \\
\hline 1 & - & - & - & - & 1 & - & 1065.67 & 500.34 & 500.34 & 1 & 801 & - & - & - \\
\hline 2 & 1198 & - & - & - & 2 & 1 & 1432.33 & 1997.67 & 1997.67 & 2 & - & - & 1 & 1 \\
\hline 3 & - & 1302 & 1203 & 1203 & 3 & 1665.67 & - & - & - & 3 & - & - & - & - \\
\hline 4 & - & - & - & - & 4 & 832 & 1 & 1 & 1 & 4 & - & 2 & - & - \\
\hline 5 & 302 & - & - & - & 5 & 1 & 1 & 1 & 1 & 5 & - & 1699 & 1799 & 1799 \\
\hline 6 & 999 & 199 & 298 & 298 & 6 & - & - & - & - & 6 & - & 799 & 700 & 700 \\
\hline 7 & 1 & 999 & 999 & 999 & 7 & - & - & - & - & 7 & 799 & - & - & - \\
\hline
\end{tabular}

Table 11

Number of workers for each shift for months 1 to 11

\begin{tabular}{llllllll}
\hline $\mathrm{j}$ & 1 & 2 & 3 & 4 & 5 & 6 & 7 \\
\hline $\mathrm{t}=1$ & 16 & 18 & 18 & 16 & 18 & 15 & 15 \\
$\mathrm{t}=2$ & 15 & 16 & 18 & 15 & 15 & 15 & 15 \\
$\mathrm{t}=3$ & 14 & 14 & 14 & 14 & 14 & 14 & 14 \\
\hline
\end{tabular}


Table 12

Number of workers for each shift for month 12

\begin{tabular}{lccccccc}
\hline $\mathrm{j}$ & 1 & 2 & 3 & 4 & 5 & 6 & 7 \\
\hline $\mathrm{t}=1$ & 19 & 19 & 19 & 18 & 19 & 17 & 16 \\
$\mathrm{t}=2$ & 15 & 18 & 19 & 15 & 16 & 15 & 15 \\
$\mathrm{t}=3$ & 15 & 15 & 15 & 15 & 15 & 15 & 15 \\
\hline
\end{tabular}

\section{Conclusion}

Textile products are one the most important needs of human beings and role of the textile industry in the growth of the global economy is significant. Hence production planning in this industry is very important but there are a few studies in this field. So in this paper we proposed a model for a textile firm that produces yarn and we attempted to consider the two major of constraint including water consumption and staffing in our model.

All the data are obtained from manager and workers from their experience. The firm can work 3 shift per day and all days of the week if needed. It means that maybe some shifts don't work. There are two types of technologies for manufacturing yarn and each technology has a production capacity. The initial amount of capacity of each technology at the beginning of period 1 is considered. Also capacity addition is allowed if needed. There is a limitation of water consumption due to limitation of input water to the firm. Number of required workers for each day and also lower and upper bound of number of required workers for each shift is given. It assumes that all workers are able to work with two technologies. Orders receive weekly to the firm and are same for first 11 months of the year but in $12^{\text {th }}$ month order is increased because of the New Year. Setup times are considered in our model and failure times are reduced from the available time for each day. Also inventory holding is considered and there are some inventory at the beginning of period 1 . In solution procedure we should care that for each month the initial amount of inventory should be modified and initial inventory for each month is inventory at the end of the last month. Because textile industry is a MTO industry, this constraint is considered in our model. The cost are discounted by using the discount factor of 0.02 and selling price are using discount factor of 0.05 . But in month 4, 5, 6, 8, 9, 10 and eleven the costs and selling prices are same as previous month.

We solved the model by GAMS. Analyzing the result we discover that in some shifts we just produce $1 \mathrm{~kg}$ and it's not economic for the firm. Hence we can allocate this production to another shifts or another technology and we showed that this transfer has not a significant change in objective value. The optimal number of workers per shift of a day is obtained too.

The future research can include the stochastic programming which demands are stochastic and also a scenario based stochastic programming may be implemented. Also we can consider a flexible technology to produce yarn and compare it to pure dedicated technology to choose the best one.

\section{Acknowledgement}

The authors would like to thank the anonymous referees for constructive comments on earlier version of this paper.

\section{References}

Adamopoulos, G., Karacapilidis, N., \& Pantazopoulos, S. (1994). Production management in the textile industry using the "YFADI" decision support system. Computers \& chemical engineering, 18, S577-S583.

Bruce, M., Daly, L., \& Towers, N. (2004). Lean or agile: a solution for supply chain management in the textiles and clothing industry?. International journal of operations \& production management, 24(2), 151-170. 
Calosso, T., Cantamessa, M., Vu, D., \& Villa, A. (2003). Production planning and order acceptance in business to business electronic commerce. International Journal of Production Economics, 85(2), 233-249.

Ceryan, O., \& Koren, Y. (2009). Manufacturing capacity planning strategies. CIRP Annals Manufacturing Technology, 58(1), 403-406.

Chen, Z. L., Li, S., \& Tirupati, D. (2002). A scenario-based stochastic programming approach for technology and capacity planning. Computers \& Operations Research, 29(7), 781-806.

Collins, P., \& Glendinning, S. (2004). Production Planning in the Clothing Industry: Failing to Plan is Planning to Fail. Control, 1, 16-20.

De Toni. A., \& Meneghetti. A. (2000). The production planning process for a network of firms is the textile-apparel industry. International Journal of Production Economics, 65(1), 17-32.

Elamvazuthi. I., Ganesan. T., Vasant. P., \& Webb. J. F. (2010). Application of a fuzzy programming technique to production planning in the textile industry. International Journal of Computer Science and Information Security, 6(3), 238-243.

Eppen, G. D., Martin, R. K. and Schrage, L. (1989). OR practice-a scenario approach to capacity planning. Operations Research, 37(4), 517-527.

Ferraris. G. and Morini. M. (2004). Simulation in the textile industry: production planning optimization. Industrial Simulation -International conference, 429-436.

Ford, F. N., \& Rager, J. (1995). Expert system support in the textile industry: End product production planning decisions. Expert Systems with Applications, 9(2), 237-246.

Forza, C., \& Vinelli, A. (1997). Quick response in the textile-apparel industry and the support of information technologies. Integrated Manufacturing Systems, 8(3), 125-136.

Hodge, G. L., Goforth Ross, K., Joines, J. A., \& Thoney, K. (2011). Adapting lean manufacturing principles to the textile industry. Production Planning \& Control, 22(3), 237-247.

Karabuk, S. (2008). Production planning under uncertainty in textile manufacturing. Journal of the Operational Research Society, 59(4), 510-520.

Karacapilidis, N. I., \& Pappis, C. P. (1996). Production planning and control in textile industry: A case study. Computers in Industry, 30(2), 127-144.

Mason-Jones, R., Naylor, B., \& Towill, D. R. (2000). Engineering the leagile supply chain. International Journal of Agile Management Systems, 2(1), 54-61.

Santana-Robles. F., Medina-Marín. J., Montaño-Arango. O., \& Seck-Tuoh-Mora. J. C. (2012). Modeling and Simulation of Textile Supply Chain through Colored Petri Nets. Intelligent Information Management, 4(5A), 261-268.

Silva. C., \& Magalhaes. J. M. (2006). Heuristic lot size scheduling on unrelated parallel machines with applications in the textile industry. Computers \& Industrial Engineering, 50(1), 76-89.

Yüksel, İ., \& Dagdeviren, M. (2007). Using the analytic network process (ANP) in a SWOT analysisA case study for a textile firm. Information Sciences, 177(16), 3364-3382. 